\title{
About Territorial Intelligence and Geographic Knowledge Bases*
}

\author{
Sobre la inteligencia territorial y las bases del conocimiento geográfico \\ Sobre inteligência territorial e as bases do conhecimento geográfico
}

Robert Laurini ${ }^{\text {a }}$

nited States Universidad de Lyon, Francia

DOI: https://doi.org/10.11144/Javeriana.cao33.atigk

Roberto.Laurini@gmail.com

ORCID: http://orcid.org/0000-0003-0426-4030

Date received: $26 / 08 / 2019$

Sylvie Servigne

Date accepted: 20/10/2019

Date published: 20/05/2020

INSA de Lyon, Francia

ORCID: http://orcid.org/0000-0003-2833-040X

Franck Favetta

Universidad de Lyon, Francia

ORCID: http://orcid.org/0000-0003-2039-3481

\begin{abstract}
:
As business intelligence is for companies, territorial intelligence is for local authorities. However, it is not the simple exportation of business intelligence concepts and tools, but overall a new discipline characterized by the amalgamation of collective human intelligence and computer intelligence. As a result, geographic knowledge bases, rules and inference engines are not only based on logic but also on topology, geometry and linguistics, and must take multiple actors' points of view into account. The scope of this paper will be to present the concepts necessary to construct such systems, i.e. to pass from intelligence to geographic knowledge engineering.
\end{abstract}

JEL Codes: R10, R50

Keywords: Territorial Intelligence, Geographic Knowledge Bases, ontologies, gazetteers, geographic rules.

\section{Resumen:}

Así como la inteligencia empresarial es para las empresas, la inteligencia territorial es para las autoridades locales. Sin embargo, la inteligencia territorial no es la simple exportación de conceptos y herramientas de inteligencia empresarial, sino una nueva disciplina caracterizada por la fusión de la inteligencia humana colectiva y la inteligencia informática. Como resultado, las bases de conocimiento geográfico, las reglas y los motores de inferencia no solo se basan en la lógica sino también en la topología, la geometría y la lingüística, y deben tener en cuenta los puntos de vista de múltiples actores. El alcance de este documento será presentar los conceptos necesarios para construir tales sistemas, es decir, pasar de la inteligencia a la ingeniería del conocimiento geográfico.

Códigos JEL: R10, R50

Palabras clave: inteligencia territorial, bases de conocimiento geográfico, ontologías, diccionarios geográficos, reglas geográficas.

\section{Resumo:}

A inteligência empresarial é para as empresas, tanto quanto a inteligência territorial é para as autoridades locais. Entretanto, a inteligência territorial não é a simples exportação de conceitos e ferramentas da inteligência empresarial, mas, em geral, uma nova disciplina caracterizada pela fusão da inteligência humana coletiva e a inteligência informática. Como resultado, as bases de conhecimento geográfico, as regras e motores de inferência não só estão baseados na lógica, mas também na topologia, a geometria e a linguística, além de ter em conta os pontos de vista de múltiplos atores. $\mathrm{O}$ alcance deste documento será apresentar os conceitos necessários para construir tais sistemas, isto é, passar da inteligência à engenharia do conhecimento geográfico.

Códigos JEL: R10, R50

Palavras-chave: inteligência territorial, bases do conhecimento geográfico, ontologias, dicionários geográficos, regras geográficas.

\section{Author notes}

\footnotetext{
${ }^{a}$ Corresponding author. E-mail: Roberto.Laurini@gmail.com
} 


\section{Introduction}

How to efficiently manage a city or to plan a territory under the perspective of sustainable development? How to involve citizens in thinking about their future? What can be the assistance of information technologies in this context? What can be the main requirements for organizing smart cities? Possible answers lie in the concept of territorial intelligence.

Even if computers have been used in urban and environment planning (Baxter, 1976) from several decades especially under the form of Geographic Information Systems -GIS- (Laurini, 2001) for storing, analyzing and mapping, little has been made in the use of artificial intelligence in this domain. Moreover, the involvement of citizens is also a key-issue in this perspective.

In the context of companies, business intelligence is overall seen as the use of business rules which are a way to model the key-elements for reasoning or making decisions essentially based on mathematical logics (firstorder, fuzzy, predicate-based, propositional, etc.). For territories, it is more complex because in addition to those logics, 2D space must be taken into account, i.e. by including topology and geometry in reasoning.

The role of this paper will be to analyze several definitions of territorial intelligence and to shape ITC tools which can help local decision-makers in their mission of planning and managing territories.

Remember that the ultimate goal is to implement such a system; but a lot of preliminary studies must be carried out and integrated into a research agenda before reaching this goal; and one of them is to model reality in order to be acceptable in artificial intelligence systems, and more precisely knowledge management systems. Three theoretical directions must be followed, (i) to clarify the semantics of geographic knowledge, (ii) to clarify what is need in territorial intelligence for efficient planning and governance, and (iii) to exhibit a knowledge model integrating all those issues.

In the literature, few studies have been made concerning knowledge-based territorial planning. However, let us mention Yeh and Qiaoô (2004) and Yigitcanlar (2016) targeting more on economic development than governance.

This paper will be organized as follows. First the role of business intelligence in companies will be examined. Then various works and perspectives dealing with territorial intelligence will be detailed. Finally, the structure of a geographic inference engine linked to a knowledge base will be presented as fundamental steps to answer the research problem.

\section{FROM BUSINESS INTELLIGENCE TO GEOGRAPHIC RULES}

There are several definitions of the expression “Business Intelligence”. For instance, Ranjan (2009) declares that: $\& \&$

Business Intelligence - BI- has two basic different meanings related to the use of the term intelligence. The primary, less frequently, is the human intelligence capacity applied in business affairs/activities. Intelligence of Business is a new field of the investigation of the application of human cognitive faculties and artificial intelligence technologies to the management and decision support in different business problems. The second related to the intelligence as information valued for its currency and relevance. (Ranjan, 2009, p. 60)

In companies, business intelligence is very commonly used because benefits are important, and is always linked to knowledge, and in particular, rules. According to von Halle:

business rules are the ultimate levers with which business management is able to guide and control the business. In fact, the business's rules are the means by which an organization implements competitive strategy, promotes policy, and complies with legal obligations. (von Halle \& Goldberg, 2006, p. 25) 
Moreover, Joosten, Wedemeijer, \& Michels (2010) declare that a rule must have a scope, stakeholders and are verifiable. For Ross (2011), rules must be considered as first-class citizens in information technologies and can be essentially modeled by IF-THEN fact or IF-THEN action.

As business intelligence appears as the basis for the management of companies, what about the management and planning in local authorities in which several stakeholders can have very different points of view with different background, experiences and knowledge? This will be the scope of this paper to examine how business intelligence can be transformed into territorial intelligence.

\section{TERRITORIAL INTELLIGENCE}

\section{In 2004, Bertacchini defined territorial intelligence as:}

an informational and anthropological, regular and continuous process initiated by local actors, physically present and/or remote, who appropriate some space resources by mobilizing and then transforming the energy of the territorial systems into the figuratively project's ability. As such, territorial intelligence can be assimilated to territoriality which results from the phenomenon of appropriation of the resources of a territory and then to transfers of responsibilities between local actors from different cultures. The objective of this approach is to ensure, literally as well as figuratively, to equip the territorial level to be developed what we have named the territorial formal capital. (Bertacchini, 2004, online consultation, plain text)

But, according to Girardot (2008), a first definition is as follows "Territorial intelligence is the science having for object the sustainable development of territories and having for subject the territorial community". More precisely, he continues by claiming:

Territorial intelligence is a way for researchers, for the actors and the territorial community to acquire a better knowledge of the territory, but also to have a better control of its development. The appropriation of technologies of information and communication, and the information itself, is a necessary step to actors for entering into a learning process that will enable them to be relevant and efficient. Territorial intelligence is particularly useful to help the territorial actors to plan, define, animate and evaluate the policies and actions of sustainable territorial development. (Girardot, 2008, online consultation, plain text)

Then in 2010, Girardot declared "If there is a relationship between economic intelligence and territorial intelligence in the sense where they use both technologies of information, they are different however in what concerns their objectives for development and governance" (Girardot, 2010, online consultation, plain text).

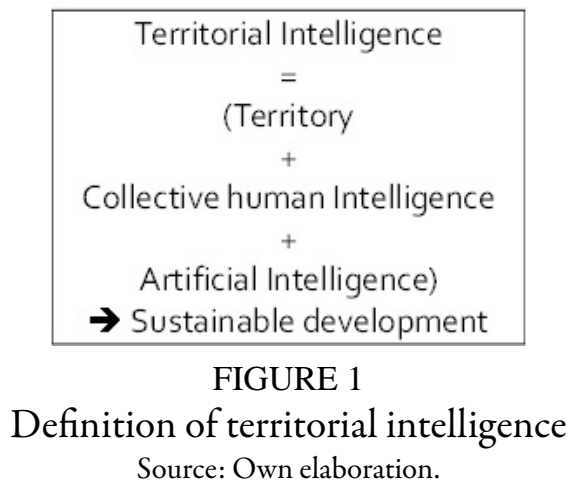

All those definitions refer to governance and decision-making, but for our concern, we think that the crossfertilization between human intelligence and computer intelligence must be included. So, let us propose a schema as illustrated in Figure 1 in which territorial intelligence supposes to deal with some territory where people are living, and with the assistance of artificial intelligence towards is a path to sustainable development. In other words, the combination of collective human intelligence with computer intelligence must lead to a better future. 


\section{Collective human intelligence}

One of the key aspects of urban planning is public participation. The ways of citizens are involved in urban planning can vary a lot from countries. Even if the number of existing experiments is very limited, we think of a paramount importance in a modern democracy to offer city-dwellers some tools for, at the maximum for designing the city, or at the minimum, to be fully aware about what their future urban environment will be. In order to reach those ideals, among the problems to solve, let us mention:

- Participative plan design, that is to say the way of involving citizens in the design of local plans; one of the possibilities is the organization of debates concerning environmental and urban planning;

- Urban plan visualization: the way to present urban plans, not only map statements, but also written statements. Apparently map statements look easier to be understood, but studies have showed that a lot of people do not understand maps, especially when the contents bear some prescriptive juridical aspects.

- Opinion collection and synthesis: some people can give their opinions, or different remarks regarding the proposed plans. What kind of visual computer languages to offer them, especially in order to precise modifications of alternatives? What kinds of mechanism to provide for synthesizing those opinions? The existing citizen forums provide an interesting solution to this issue.

- Information distribution and communication between citizens and the city council: for this task, Internet can be used as a medium for exchanging information, ideas, maps between all actors.

- Facilities organizations: in order that scores of people with limited knowledge in computing can also participate by understanding plans, reading maps and written statements, giving their opinions and playing with urban virtual reality, the arrangement of the premises must be carefully studied.

In this domain, we need to distinguish a very common character in the domain of public participation, named NIMBY (Not in my backyard!) representing people defending only their own property, often very aggressive in environmental dispute, and using general interest to protect their private interests. Sometimes, they "pollute" the debate. According to Craig (1998), organizing public participation in a city can have the following objectives:

- Expand the public's role in defining questions and making decisions in which location or geography have a bearing on the issues addressed;

- Increase public participation in the identification, creation, use and presentation of relevant information in various problem-solving contexts; and,

- Enable wider public involvement of stakeholders in planning, dispute resolution and decisionmaking environments through a computer-based public participation process.

More practically, the public can be involved for the following collaborative planning processes such as public dispute resolution, facility siting/design review, futures and scenario planning.

The problem of the various degrees of involving people in land use planning is very old. In 1969, Arnstein (1969) proposed the first ladder for public participation with eight steps, manipulation, therapy, informing, consultation, placation, partnership, power delegation and citizen control. But this ladder was not seen adequate. Starting from a previous work made some years before, Kingston (1998) has proposed a six-step ladder (Figure 2) which appears more relevant for our purpose. Among the steps, one can successively find from bottom to top (the lower steps meaning no real public participation):

- Public right to know; in this first level phase, the public has only the possibility to be aware that some planning issue could be of interest; 
- Informing the public: here the concerned local authority implements some action plan in order to inform the people; but the people have no possibility to react;

- Public right to object: here the city-dwellers may say yes or no to a project, but have no possibility to react neither to amend it;

- Public participation in defining interests, actors and determining agenda: this is the very first level of participation;

- Public participation in assessing consequences and recommending solutions: now the public is truly involved in analyzing the impacts of possible decisions and can recommend solutions which can be accepted to be implemented;

- Public participation in final decision: this is real participation in the final decision; the decision is not only made by elected officers (city-councilors for instance), but each citizen can vote whether or not to accept the plan.

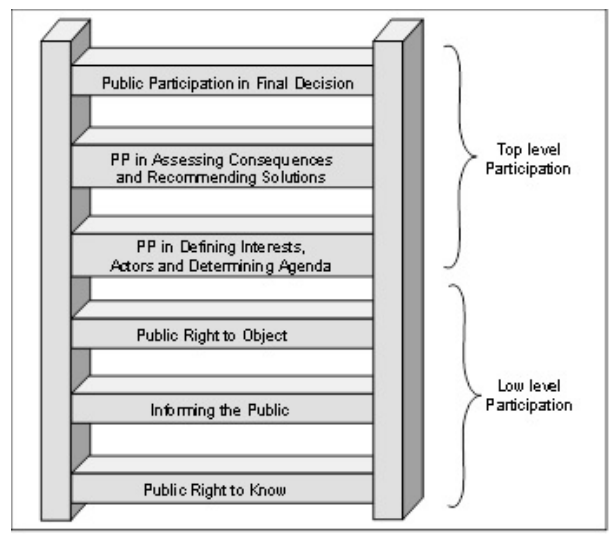

FIGURE 2

The public participation ladder according to Kingston (1998) with modifications Source: Own elaboration.

As a conclusion to this section, let us say that Territorial Intelligence by involving and empowering citizens at the higher level, is truly at the upper layer of this ladder. But the amalgamation of human collective and computer-based intelligence is truly a challenge for territorial planning and management. A key-element is that other disciplines than logics must be integrated to solve those issues.

\section{Geographic reasoning}

The purpose of a declarative rule-based model is to authorize automatic reasoning. In contrast to expert systems of the past (Kim et al., 1989; Batty \& Yeh, 1991) that were using simple logics, in our case, it will be very different. Here are some examples:

- Define the location of a new airport, a new hospital, a new stadium, social housing, etc.

- Check the compliance of a building vis-à-vis planning statements.

- Determine the best way to get from a place to another.

- Organize a policy of green spaces.

- Determine a transit policy

- Limiting crime in a city.

- Build a tour through $\mathrm{x}$ and $\mathrm{y}$.

- Build garbage collection circuits.

- Determine the most polluted, noisiest, places.

- Etc. 
From these examples, it can be seen that geographic reasoning refers not only to logics (predicate, propositional or fuzzy) but also to other mathematical disciplines such as spatial reasoning by the integration of topology and computational geometry, graph theory, spatial analysis, simulation techniques, logic fuzzy and reasoning, multi-criteria decision theory and operations research.

\section{Semantics of geographic rules}

In addition to administrative rules, other statements could lead to geographic rules. In fact, let us look at some of them:

- In the United Kingdom, one drives on the left.

- In Canada, the majority of the population lives along the border with the United States.

- Each capital city has an international airport nearby.

- Between two capitals, in general, there are direct flights.

- The more you go northward, the colder (but locally this is not always true).

- The more you climb a mountain, the colder.

- Heavy rain upstream, downstream flooding.

- Mosques are oriented towards Mecca.

- If there is unemployment, the creation of companies or industrial areas must be encouraged.

- If a plot is adjacent to an airport, it is necessary to limit the height of buildings.

- It is forbidden to open a new pharmacy within 500 meters of a yet existing other.

- A good practice in the Mexico is to use a bus to go from Puebla to Oaxaca City.

Another aspect that corresponds to the status of a rule, i.e. modeling should specify the semantics of the rule:

- The implication is automatic (truth of nature), "if it rains, you get wet".

- The implication can be viewed as a recommendation or a good practice, "if it is raining, take your umbrella”.

- A law may decide an inference, i.e. there exists a legal obligation; otherwise, sanctions can generally be applied.

- A law may open possibilities; in this case, the rule provides several open alternatives or options, but none is required.

- Some rules can be regarded as a constraint as the limits on the height of buildings.

- A local plan generates rules as part of a more general law; so a rule can supersede another rule; exceptions may exist; in some cases, existing illegal features such as buildings must also be considered: indeed such a thing exists in the real world, but it should not exist according to a precise rule; i.e. do not forget exceptions, exemptions and transgressions.

- The so-called best practices can be considered both as recommendations and/or as local rules.

- Spatial data mining and analytics consider items or patterns that are frequent linked or things that appear frequently together; do not forget the support and confidence in those association rules.

- A rule is valid only on a clearly defined territory; this space can be called the jurisdiction of the rule (for example: a country).

- Some geographic local rules can supersede global rules; in this case, the places where the local rules applied must be inside the jurisdiction of the global rule, for instance for microclimate rules. 
- The language in which the rule is defined is an important characteristic of a rule; the language defines place-names and ontology; generally there is only one language in one place, but there are places where many languages must be considered; example, the rules of the European Union.

- Some rules (metarules) can define new land-use concepts; a consequence is that those new concepts must be integrated into ontologies.

- Sometimes different actors may have different rules because they have different points of view about reality. The methods based on multi-criteria and multi-actor decision making processes can help support those aspects.

As a consequence, the following model can be proposed in which the jurisdiction is the place where the rule or the metarule hold (see Figure 3). More details could be found in Laurini, Servigne, \& Favetta (2016).

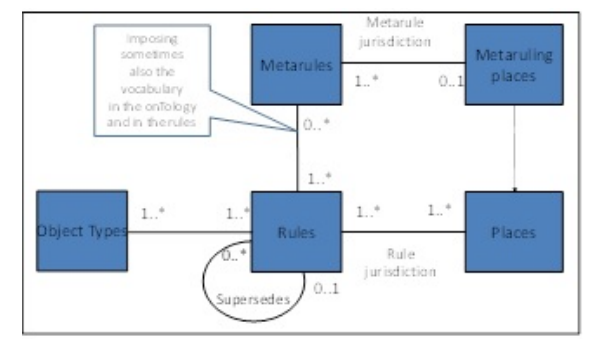

FIGURE 3

Relationships between places and rules Source: Own elaboration.

\section{Rules and Geographic Knowledge Bases}

Once the language and territory selected, a geographic knowledge base may include an ontology, a gazetteer, geographic objects and the relationships between these objects, rules and mathematical models, together with external knowledge. Remember that Laurini (2017):

1. Ontologies, as especially geographic ontologies or urban ontologies must not only include feature types, but also spatial relationships between them as explained in Kavouras, Kokla \& Tomai (2005), Laurini (2012) and Laurini (2014).

2. Gazetteers as toponym dictionaries or databases integrate all place-names (see Keßler, Janowicz \& Bishr, 2009; Jakir, Hećimović \& Štefan, 2011; Laurini, 2015).

3. Mathematical models encapsulate some kinds of geographic knowledge in a procedural way, for instance in physical geography; those models can be invoked by geographic rules when necessary.

4. Geographic rules must be the key-element of the knowledge base by integrating in their formalism not only geographic objects and relations, but also ontologies, gazetteers and mathematical models.

5. External knowledge which can be useful in geographic reasoning, may come either from the vicinity of the jurisdiction or from other sources. For more details, refer to Laurini et al. (2016).

As input, there will be a territorial project to study so as to determine, through the geographic inference engine, the consequences in output. These consequences will be grouped in a result of feasibility that may be in the form of maps, schemata, texts, etc. Figure 4 shows such a knowledge base linked to a geographic inference engine that allows reasoning. 


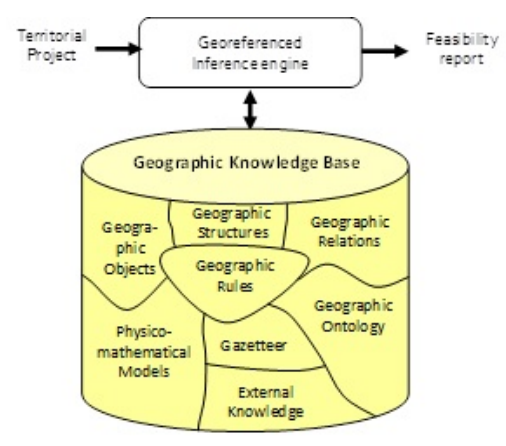

FIGURE 4

Structuring a geographic knowledge base Source: Own elaboration.

\section{Geographic Rules Modeling}

Geographic rules (Figure 5) have a lot of special characteristics, origin, temporal dimension, components, mathematic tools, usage, modality, and management. Regarding the computer representation of business rules, several extensions of XML have been provided, but all of them are based on logic without taking into account aspects coming from topology and computational geometry. But we think that it is too early to design such an adapted representation. This is the reason why a first version of a mathematical language has been created to model geographic rules. For the complete grammar, refer to Laurini (2019).

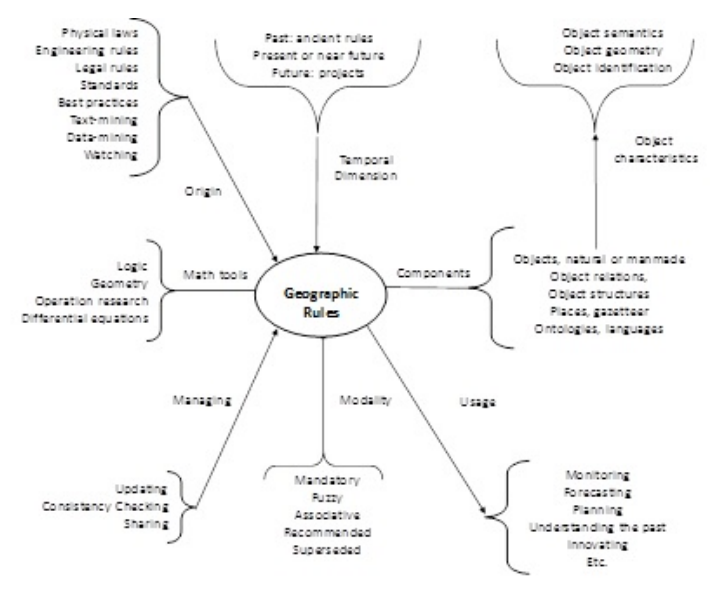

FIGURE 5

Characteristics of geographic rules Source: Own elaboration.

This language is based on set theory integrating computational geometry and topology. The simplified structure is as follows:

- Context, including declarations, definitions and possibly constraints ending by “:”;

- Boolean conditions ending by " $\Rightarrow$ ";

- Consequents ending by "

When the relations must always hold, the entailment symbol " $F$ " is used which is sometimes called "double turnstile" or semantic consequence. Among important concepts, let us mention:

- Spatial concepts: Earth, representing the planet which is supposed full of Terr (= territories), 
- Ontological concepts: Geographic Objects (sometimes noted GO) regrouping all categories of objects existing in the Earth, and

- Projects representing objects during the designing process; some of them can be said geographicobject-to-be.

To illustrate, let us take several examples. Rule 1 concerns the project of a recreational park which was approved and implemented: "if a projected park is approved and implemented, then the opening ceremony can be launched, and the park will be integrated as a real geographic object into the knowledge base". This could be considered as a business rule. However, it has two main attributes, for instance Toponym $(P)$ $=$ "Winston Churchill Park", and Geom $(P)=\operatorname{Polyg}(3731,7128 ; 3903,7133 ; 3905,7341 ; 3839,7$ 346; $3814,7349)$.

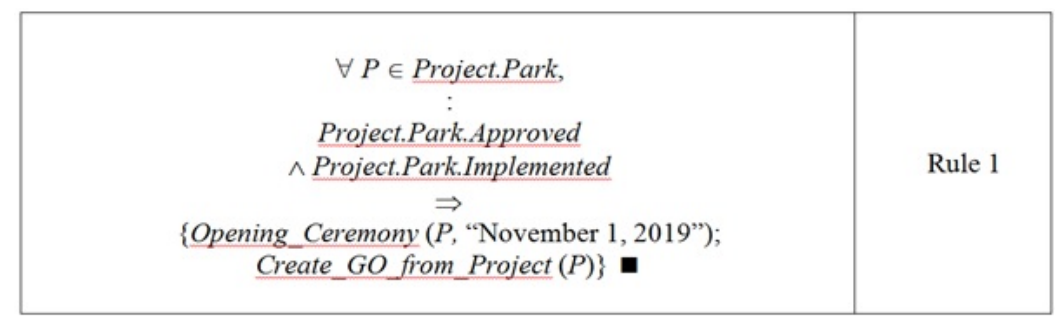

Rule 2 is more complex concerning agriculture, drought and irrigation: "if a piece of land is dry, and below there is a groundwater body with sufficient water, irrigation is possible”. Here we need Below which is a topological relation, and some fuzzy variables.

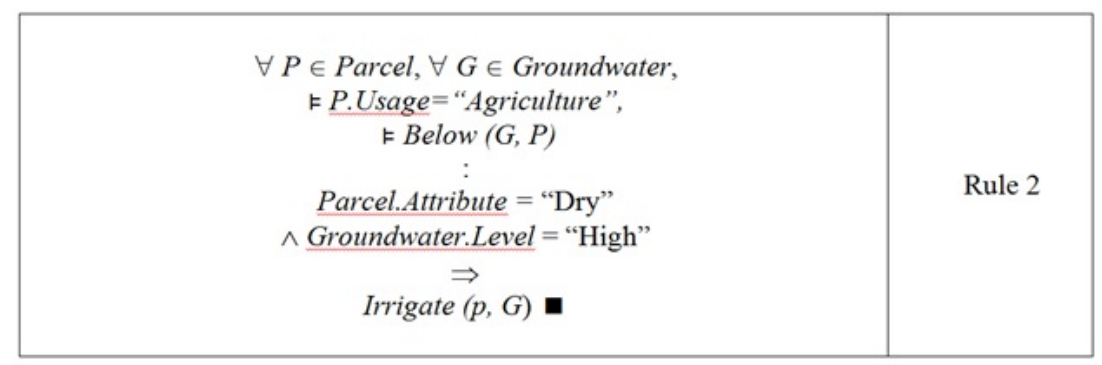

The third rule stipulates that at the vicinity (less than 200 meters) of an historic building (listed monument), no modifications of building are allowed (see Figure 6). Here we need both topological relations (disjoint, inside) and geometric functions (buffer, union).

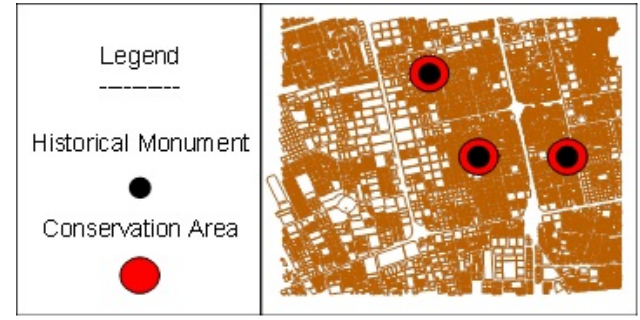

FIGURE 6

Constructions or modifications forbidden around historical monuments Source: Own elaboration.

This rule can be written: 


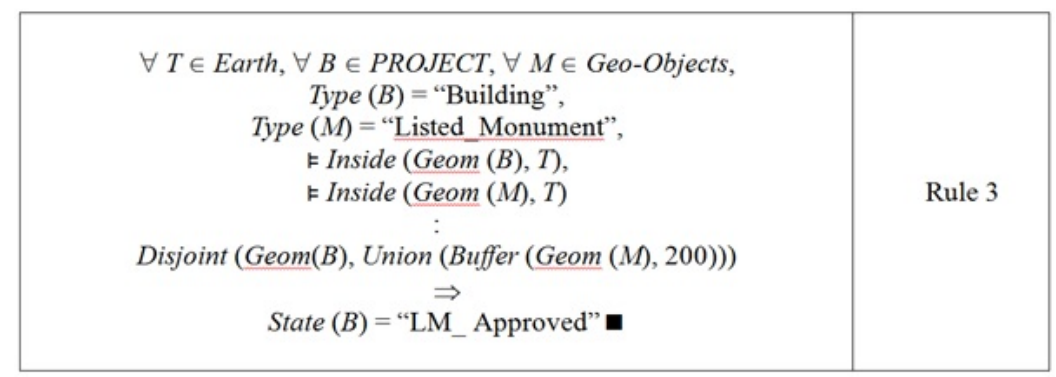

\section{Final remarks}

The goal of this paper was to emphasize the importance of human and artificial intelligence for territorial governance. By means of a geographic knowledge base, local shareholders can, not only store their own knowledge about the territory they want to manage or to plan, but also make simulations to about the future.

We need to continue the analysis in order to include all aspects of geographic knowledge. By doing so, an efficient model will be proposed especially for geographic rules.

For the moment being, only 2D and 2.5D knowledge was dealt with, but we have the perspective to include as far as possible three-dimensional and temporal issues.

As explained in the introduction, this research can be seen as a preliminary step to design and implement a knowledge-based system for territorial intelligence. More generally, other preliminary steps should include:

- Identification of knowledge chunks, including rules, and their characteristics,

- Clarification of the differences between a GK system and a GK infrastructure,

- Identification of temporal and 3D rule semantics,

- Identifying a collection of examples and simple applications for early prototyping,

- Definition of a computer language for geospatial rules,

- Structuring and populating knowledge bases,

- Design of a language for modeling projects and scenarios as input,

- Identifying output representations (geovisualization) suitable for all stakeholders,

- Definition of a language for project and scenario modeling,

- Primary specifications of a geographic inference engine,

- Implementation, testing and execution of the engine,

- Integration of narrative and visual knowledge,

- Assessment of the result and possible modifications of the language or the engine,

- Definition of real-life examples,

- Acceptability by stakeholders.

Only after those steps are fully completed, such a system will be operational and applied to a real territory.

\section{References}

Arnstein, S. R. (1969). A ladder for citizen participation. Journal of the American Institute of Planners, 35(7), 216-244. https://doi.org/10.1080/01944366908977225

Batty. M., \& Yeh, T. (1991). The promise of expert systems for urban planning. Computers, Environment and Urban Systems, 15(3), 101-108. https://doi.org/10.1016/0198-9715(91)90001-T

Baxter, R. S. (1976). Computer and statistical techniques for planners. London: Methuen. 
Bertacchini, Y. (2004). Entre information et processus de communication: L'intelligence territoriale, 3èmes Rencontres TIC \& Territoire: quels développements ? Lille, May, Revue Information Sciences for Decision-Making, http://is dm.univ-tln.fr/PDF/isdm16/isdm16a154_bertacchini.pdf

Craig, W. J. (1998). The internet aids community participation in the planning process. Computer, Environment and Urban Systems, 22(4), 393-404. https://doi.org/10.1016/S0198-9715(98)00033-7

Girardot, J.-J. (2008). Evolution of the concept of territorial intelligence within the coordination action of the European network of territorial intelligence, p. 11, Res-Ricerca e Sviluppo per le politiche sociali, 1-2/2009. ht tp://www.territorial-intelligence.eu/portail/site/

Girardot, J.-J. (2010). Qu'est-ce que l'intelligence territoriale? Collaboratif-info. Online consultation. 28 juin. http:// www.collaboratif-info.fr

Jakir, Ž., Hećimović, Ž., \& Štefan, Z. (2011). Place Names Ontologies. In A. Ruas (ed.), Advances in cartography. Lecture notes in geoinformation and cartography (pp. 331-349). New York: Springer Heidelberg.

Joosten, S., Wedemeijer, L., \& Michels, G. (2010). Rule Based Design. Holland: Open Universiteit Nederland.

Kavouras, M., Kokla, M., \& Tomai, E. (2005). Comparing categories among geographic ontologies. Computers \& Geosciences, 31(2), 145-154. https://doi.org/10.1016/j.cageo.2004.07.010

Keßler, C., Janowicz, K., \& Bishr, M. (2009). An agenda for the next generation gazetteer: geographic information contribution and retrieval. Proceedings of the 17th ACM SIGSPATIAL International Conference on Advances in Geographic Information Systems (pp. 91-100). New York: ACM.

Kim, T., Wiggins Lyna, L., \& Wright, J. (eds.) (1989). Expert Systems: Applications to urban planning. New York: Springer Verlag.

Kingston, R. (1998). Accessing GIS over the Web: An aid to public participation in environmental decision making. Proceedings of the Workshop of the International Association for Public Participation, SPICE 98, Tempe Arizona, October 3-7, http://http://www.iap2.com/a_kingston.htm.

Laurini, R. (2001). Informationsystems for urban planning: A hypermedia cooperative approach. London: Taylor and Francis. 368 p.

Laurini, R. (2012). Importance of spatial relationships for geographic ontologies. In PlanningSupport Tools: Policy Analysis, Implementation and Evaluation. M. Campagna et al. (eds.), Proceedings of the Seventh International Conference on Informatics and Urban and Regional Planning INPUT. (pp. 122-134). Milano: Franco Angeli.

Laurini, R. (2014). A conceptual framework for geographic knowledge engineering. Journal of Visual Languages and Computing, 25, 2-19, http://dx.doi.org/10.1016/j.jvlc.2013.10.004i.

Laurini, R. (2015). Geographic ontologies, gazetteers and multilingualism. Journalof Future Internet, 7, 1-23. https: //doi.org/10.3390/fi7010001.

Laurini, R. (2017). Geographicknowledge infrastructure: Applications for territorial intelligence and smart cities. London: Elsevier \& ISTE.

Laurini, R. (2019). A mathematical language for the modeling of geospatial static rules. Journal of Visual Language and Computing, 2009(1), 1-13. http://www.ksiresearch.org/jvlc/journal/JVLC2019N1.pdf

Laurini, R., Servigne, S., \& Favetta, F. (2016). An introduction to geographic rule semantics. In Proceedings of the 22nd International Conference on Distributed Multimedia Systems, Salerno, Italy (pp. 91-97), November 25-26. Published by Knowledge Systems Institute.

Ranjan, J. (2009). Business Intelligence: Concepts, components, techniques and benefits. Journal of Theoretical and Applied Information Technology, 9(1), 60-70. http://www.jatit.org/volumes/research-papers/Vol9No1/9Vol9 No1.pdf

Ross, R. G. (2011). More on the if-then format for expressing business rules: Questions and answers. Business Rules Journal, 12(4). http://www.brcommunity.com/a2011/b588.html.

von Halle, B., Goldberg, L. \& Zachman, J. (2006). Business Rule Revolution. Running Business, the Right Way. Silicon Valley: Happy About. 324 p. 
Yeh, A. G., \& Qiaoô, J. J. (2004). Component-based approach in the development of a knowledge-based planning support system (KBPSS). Part 1: The architecture of KBPSS. Environmentand Planning B: Planning and Design, $31,517-537$.

Yigitcanlar, T. (2016). Editorial: Dimensions of knowledge-based urban development. International Journal of Knowledge-Based Development, 7(1), 1-3. https://eprints.qut.edu.au/94247/

\section{Notes}

* $\quad$ Research paper.

Licencia Creative Commons CC BY 4.0

Cited as: Laurini, R., Servigne, S., \& Favetta, F. (2020). About territorial intelligence and geographic knowledge bases. Cuadernos de Administración, 33. https://doi.org/10.11144/Javeriana.cao33.atigk 